\title{
Indicators of soil degradation in urban forests: physical and chemical parameters
}

\author{
R. M. Longo ${ }^{1}$, M. S. Reis ${ }^{1}$, C. S. Yamaguchi ${ }^{1}$, A. C. Demamboro ${ }^{1}$, \\ S. C. Bettine ${ }^{1}$, A. I. Ribeiro ${ }^{2} \&$ G. A. Medeiros ${ }^{2}$ \\ ${ }^{1}$ Pontificia Universidade Católica, PUC-Campinas, Brazil \\ ${ }^{2}$ University State of São Paulo, UNESP, Brazil
}

\begin{abstract}
The fragmentation of forest habitats in urban areas has aroused increasing interest in recent years according to the growing environmental problems. The fragmentation of theses ecosystems is caused, in general, by the pressure of housing, agriculture and industry, causing losses in biodiversity and problems of soil degradation in the border areas of theses remnants. The establishment of indicators of soil degradation becomes essential for the implementation of conservation and reclamation. This study analyzes physical and chemical characteristics of soil under different forms of vegetation in the forest surrounding the Quilombo Forest, located in Campinas/SP - Brazil, and examines the possibility of using these indices as indicators of environmental degradation in urban remnants. The parameters analyzed were: specific weight natural $(\gamma \mathrm{n})$, specific weight of solids $(\gamma \mathrm{s}) \mathrm{Ca}, \mathrm{P}, \mathrm{K}, \mathrm{Mg}, \mathrm{pH}$, organic matter, $\mathrm{H}+$ Al, Sum of Base (SB) Percent Base Saturation (V\%), Cation Exchange Capacity (CEC). The study shows that in general the different forms of land used in the study area significantly changed (or according to) the physical aspects of soil The porosity and voids of the soil stood out as the best indicators of soil physical degradation in the layer $0-20 \mathrm{~cm}$ deep. In relation to chemical indices, the soil under the cultivation of cane sugar had a significantly higher $\mathrm{pH}, \mathrm{K}, \mathrm{Ca}, \mathrm{Mg}$ and sum of bases. The areas of forest showed higher levels of phosphorus, organic matter and $\mathrm{CEC}$, indicating the importance of maintaining vegetation and replacement for the cycling of organic matter.

Keywords: remnant forest, soil physics, soil degradation.
\end{abstract}




\section{Introduction}

Environmental problems from the use of land in urban areas have attracted increasing interest from researchers around the world. In general, the factors that control the erosion processes are the kinetic force of rain, vegetation, slopes and characteristics of soil properties, including texture, bulk density, and porosity, among others. In this context, the establishment of indicators of environmental degradation and sustainability is important.

Remaining forests are the forests that have suffered degradation of nature or man [1]. Human disturbance generates a series of impacts, among which is fragmentation of ecosystems [2]. Fragmentation changes the biological phenomena and processes, simplifying the ecological systems and causing the loss of functional groups as well as severe damage to natural habitats, leading to the reduction of the population of fauna and flora, and isolating species [3].

The isolation and habitat loss pose severe threats to the planet's biological diversity, since the isolation reduces the potential for immigration, compromising the viability of the metapopulation, defined as the number of populations of organisms conspecifics occupying separate areas in the same period of time [3]. Most biodiversity is currently located in small forest fragments, historically marginalized by conservation initiatives.

The present research work aims to evaluate the changes occurring in physical and chemical parameters of soil resulting from the replacement of natural vegetation by pastures and sugar cane in the Quilombo Forest (Campinas/SP, Brazil), a cerrado fragment. This work will serve as a basis for the quantification of the soil degradation resulting from human action.

\section{Material and methods}

The Forest of Quilombo is located in the Village Florida, north of the subdistrict of Baron Geraldo, Campinas-SP, on the banks of Ribeirão Anhumas and nearby Highway Rhodia. It has a typical cerrado (savanna) vegetation and is located in an area of eutrophic Oxisol [4], which presents CW2 type climate, with average rainfall of $1381.2 \mathrm{~mm}$ and mean annual air temperature of $22.4^{\circ} \mathrm{C}$. It is less than 40 ha and surrounded by plantations of cane sugar, pastures and condominiums.

Soil samples were collected at 6 points set out in the preliminary survey of the area, namely: 1 . preserved forest. 2. degraded forest (near pasture) 3. abandoned pasture 4. preserved forest 5. degraded forest (near sugar cane), 6. sugar cane, as can be seen in Figure 1.

The undisturbed soil samples were collected using a metal ring with a diameter of $4.6 \mathrm{~cm}$ and height of $4.8 \mathrm{~cm}$. For the analyzes of 10 samples were taken fertility simple plot, a total of 24 composite samples in the $0-0.20 \mathrm{~m}$ depth which were then dried and sieved to yield the air-dried soil. 


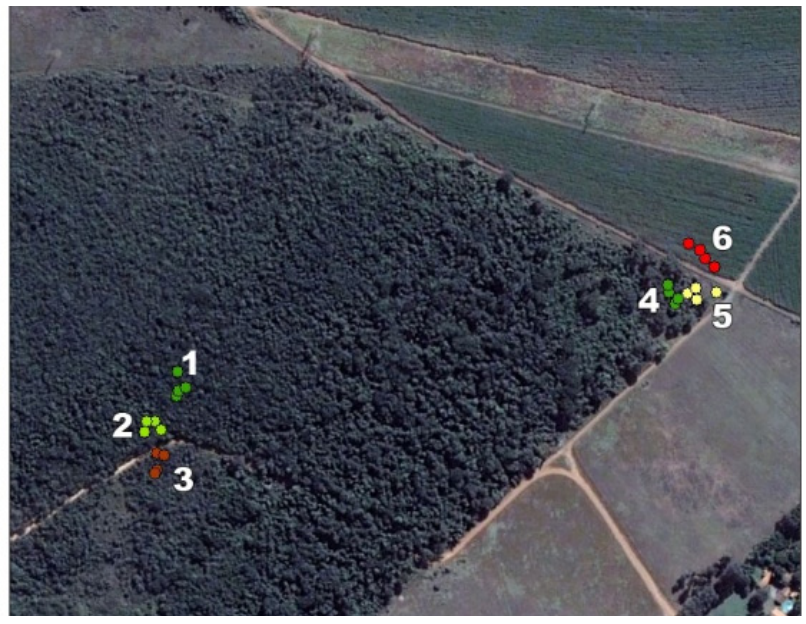

\section{Legenda}

- Mata

- Mata de Borda

- Pasto Sujo

- Pasto

- Cana-de-Açúcar

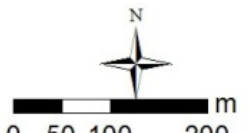

$0 \quad 50100 \quad 200$

UTM. WGS84. Fuso 235

Figure 1: Points where the collections of soil were made [7]. No real value mapping. Edit: the author (Reis, M.S.).

Samples of dried soil air were subjected to chemical and grain size analysis, determining the $\mathrm{pH}\left(\mathrm{CaCl}_{2}\right)$, the content of organic matter by oxidation with $\mathrm{H}_{2} \mathrm{SO}_{4}$ and by colorimetric quantification; available phosphorus (P) and the potassium $(\mathrm{K})$, calcium $(\mathrm{Ca})$ and magnesium $(\mathrm{Mg})$, extracted by ion-exchange resin, and quantified by colorimetry $\mathrm{P}$ and $\mathrm{K}, \mathrm{Ca}$ and $\mathrm{Mg}$ were determined by atomic absorption spectrophotometry, and the content of aluminum (Al) extracted by $1 \mathrm{~N} \mathrm{KCl}$ and determined by acid-base titration and the values for $\mathrm{T}=$ cation exchange capacity and base saturation $=\mathrm{V}$, were obtained by detailed calculation of the analytical methods discussed in [5].

The specific weight natural $(\gamma \mathrm{n})$, specific weight of solids $(\gamma \mathrm{s})$ were determined according to the adaptation of the ABNT NBR 6508, NBR 6459/84 and NBR 7180/84 [6,7]. Through calculations, we determined the apparent specific dry weight $(\gamma 0)$, the saturated specific weight $(\gamma \mathrm{sat})$, submerged specific weight $(\gamma)$.

$$
\begin{gathered}
\gamma 0=\frac{\gamma \mathbf{n}}{1+\mathrm{W}} \\
e=\frac{\gamma s}{\gamma^{0}}-\mathbf{1} \\
n=1-\frac{\gamma 0}{\gamma s} \\
\gamma \text { sat }=(1-\mathrm{n}) \gamma \mathrm{s}+\mathbf{n} \cdot \gamma \mathbf{a} \\
\gamma^{\prime}=\gamma s a t-\gamma a
\end{gathered}
$$

where: $\gamma \mathrm{a}=$ specific weight of water, adopted as a $\mathrm{gf} / \mathrm{cm}^{3}$ 
Table 1 shows the information of humidity and particle size fractions of soil in fields of study.

Table 1: $\quad$ Moisture and particle size fractions in the study areas.

\begin{tabular}{|c|c|c|c|c|}
\hline \multirow{2}{*}{ area } & Clay & Silt & Send & Moisture \\
\cline { 2 - 5 } & \multicolumn{3}{|c|}{$\mathrm{g} \mathrm{kg}^{-1}$} & $(\%)$ \\
\hline preserved forest (P1) & 395,0 & 160,6 & 444,4 & 17,9 \\
\hline degraded Forest (P2) & 295,3 & 156,0 & 548,6 & 15,4 \\
\hline abandoned pasture (P3) & 240,2 & 125,7 & 634,0 & 14,4 \\
\hline preserved forest (P4) & 385,5 & 90,7 & 523,7 & 15,2 \\
\hline Pasture (P5) & 383,2 & 83,5 & 533,2 & 17,2 \\
\hline sugar cane (P6) & 406,7 & 83,7 & 509,5 & 18,6 \\
\hline
\end{tabular}

The results were subjected to analysis of variance $(\mathrm{P}<0.05)$ and, in cases where the F-test proved significant, we applied the Tukey test to compare means of six repetitions [8] using the programs SISVAR ASSISTAT 5.3 and 7.6.

\section{Results and discussion}

The area is highly impacted by anthropogenic factors, showing several degradation factors such as disposal of waste from tree trimming to plastics, construction materials, wood, paint cans and other aspects of soil degradation, such as erosion, seen in Figure 2.
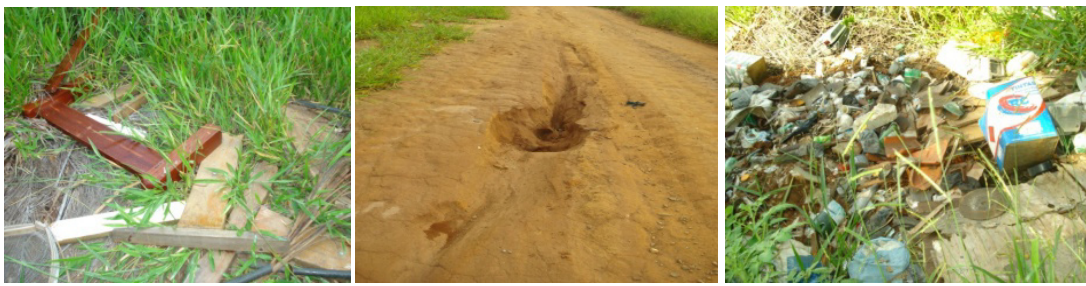

Figure 2: Waste disposed in the forest edge of the Quilombo (Yamaguchi, C.S. e Reis, M.S.).

This degradation can promote significant changes in physical and chemical parameters of forest soil and may hinder the process of restoring these ecosystems.

For some parameters such as apparent specific dry soil voids, specific gravity saturated and submerged specific weight, the point closest to the forest of cane sugar had characteristics of both the forest and Lawn or Forest Edge, revealing 
that this area, because it is closer to sources of degradation (traffic of people and animals, vehicles, fires, etc.) presents the most degraded soil in relation to that most central point located in the Forestry. Even for this group of data, it is observed that the values for pasture dirty and sugar cane are statistically similar.

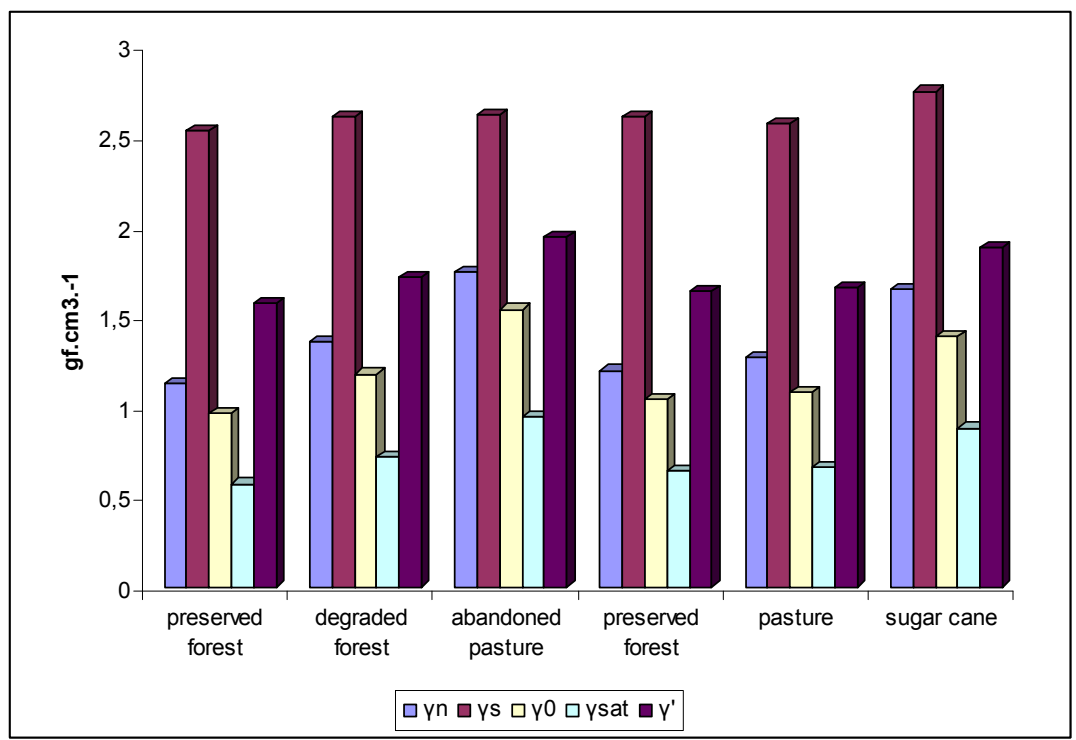

where: $=\gamma \mathrm{n}$ weight esp. natural; $\gamma \mathrm{s}=$ weight esp. the solids weight $\gamma 0=$ esp. Apparent dry; $\gamma \mathrm{sat}=$ weight esp. saturated and $\gamma^{\text {' }}=$ weight esp. submerso.

Figure 3: Averages of specific weights of the soil analysed by the Tukey test at $5 \%$ significance level.

In general, we can say that the continuous causes changes in soil physical properties, which ultimately degrade its structure. For sugar cane, it appears that the larger the crop, the greater reduction of porosity, being common to soils cultivated with sugar cane, with high levels of compression [10]. Thus, taking into consideration that the area has undergone several anthropogenic changes similar to those observed for planting, it is natural that the parameters have similar values, especially in the voids and porosity, since the soil in this region is more compressed. The values presented by Degraded Forest and Pasture are also always close, indicating the presence of degradation factors common to the edge effect in the urban forest.

Table 2 presents the means and statistical analyzes of the results obtained from the fertility of the soil chemical analyzes. A general one can observe that the level of phosphorus (P) showed as similar in the preserved forest (P1) as the degraded forest (P2). Organic matter (M.O) in the abandoned pasture showed value below was obtained compared to the preserved forest (P1) and forest degraded Forest (P2) because the soil has been exposed, without any litter. 
Table 2: $\quad$ Averages of four replications of the chemical parameters analyzed according to the type of use of the soil (macro nutrients).

\begin{tabular}{|c|c|c|c|c|c|c|c|c|c|c|}
\hline area & P Resina & M.O. & $\mathrm{pH}$ & $\mathrm{K}$ & $\mathrm{Ca}$ & $\mathrm{Mg}$ & $\mathrm{H}+\mathrm{Al}$ & SB & CTC & $\mathrm{V}$ \\
\hline & $\mathrm{mg} / \mathrm{dm}^{3}$ & $\mathrm{~g} / \mathrm{dm}^{3}$ & $\mathrm{CaCl} 2$ & \multicolumn{6}{|c|}{$\mathrm{mmolc} / \mathrm{dm}^{3}$} & $\%$ \\
\hline $\begin{array}{l}\text { preserved forest } \\
\text { (P1) }\end{array}$ & $3,25 \mathrm{a}$ & $29,00 \mathrm{ab}$ & $3,80 \mathrm{~b}$ & $1,08 \mathrm{a}$ & $3,25 \mathrm{~b}$ & $1,75 \mathrm{~b}$ & $97,75 \mathrm{a}$ & $6,08 \mathrm{~b}$ & $103,83 a$ & $6,00 \mathrm{~b}$ \\
\hline $\begin{array}{l}\text { degraded Forest } \\
\text { (P2) }\end{array}$ & $3,50 \mathrm{a}$ & $29,25 \mathrm{ab}$ & $3,80 \mathrm{~b}$ & $1,48 \mathrm{a}$ & $3,25 \mathrm{~b}$ & $3,00 \mathrm{~b}$ & $92,25 \mathrm{a}$ & $7,23 \mathrm{~b}$ & $99,98 \mathrm{a}$ & $7,75 b$ \\
\hline $\begin{array}{l}\text { abandoned pasture } \\
\text { (P3) }\end{array}$ & $2,50 \mathrm{a}$ & $21,25 \mathrm{~b}$ & $3,98 \mathrm{~b}$ & $0,95 \mathrm{a}$ & $4,25 b$ & $2,00 \mathrm{~b}$ & $57,25 \mathrm{bc}$ & $7,20 \mathrm{~b}$ & $64,45 b$ & $11,00 \mathrm{~b}$ \\
\hline $\begin{array}{l}\text { preserved forest } \\
\text { (P4) }\end{array}$ & $2,25 \mathrm{a}$ & $38,50 \mathrm{a}$ & $4,10 \mathrm{~b}$ & $0,83 a$ & $8,25 \mathrm{~b}$ & $2,75 b$ & $92,50 \mathrm{a}$ & $11,83 \mathrm{~b}$ & $104,33 \mathrm{a}$ & $10,75 b$ \\
\hline Pature (P5) & $2,00 \mathrm{a}$ & $37,75 \mathrm{a}$ & $4,23 b$ & $0,83 \mathrm{a}$ & $10,75 \mathrm{ab}$ & $3,50 \mathrm{~b}$ & $80,25 \mathrm{ab}$ & $15,08 \mathrm{~b}$ & $95,33 \mathrm{a}$ & $16,25 \mathrm{~b}$ \\
\hline sugar cane (P6) & $1,75 \mathrm{a}$ & $28,75 \mathrm{ab}$ & $4,90 \mathrm{a}$ & $1,68 \mathrm{a}$ & $22,00 \mathrm{a}$ & $12,0 \mathrm{a}$ & $41,00 \mathrm{c}$ & $35,68 \mathrm{a}$ & $76,68 \mathrm{ab}$ & $45,00 \mathrm{a}$ \\
\hline $\begin{array}{c}\text { Variation } \\
\text { Coefficient (\%) }\end{array}$ & 60,28 & 18,62 & 4,89 & 34,72 & 65,23 & 67,53 & 16,3 & 60,24 & 14,42 & 56,69 \\
\hline
\end{tabular}

Observe that the $\mathrm{pH}$ in the abandoned pasture (P3) showed higher values compared to preserved forest (P1 and P4) and degraded Forest (P2) this is due to possible liming suffered in the area for the implementation of some culture in the abandoned pasture (P3). Compared to aluminum $(\mathrm{Al}+\mathrm{H})$ and $\mathrm{CEC}$ (cation exchange capacity) it is observed higher values in the preserved forest ( $\mathrm{P} 1$ and $\mathrm{P} 4)$ decreased to the degraded Forest (P2) but the level of $\mathrm{K}$ (potassium), $\mathrm{Mg}$ (Magnesium) and SB (sum of bases) are higher in the abandoned pasture (P3)., varying with lower levels in the preserved forest (P1) abandoned pasture (P3).

\section{Final consideration}

Overall, it was concluded that the specific weight natural (or natural weight) $(\gamma \mathrm{n})$, was presented as the best indicator of soil degradation for the remainder of the urban forest Quilombo Forest, to the upper soil layer $(0-20 \mathrm{~cm})$, but other parameters should be included in future studies, especially those related to the establishment of rehabilitation programs of degraded areas.

The results indicated that overall the soil under cultivation of sugar cane had higher values of $\mathrm{pH}, \mathrm{K}, \mathrm{Ca}, \mathrm{Mg}$ and sum of bases, and these values probably resulted in adduction and liming suffered by culture. The areas of forest showed higher levels of phosphorus, organic matter and CEC, indicating the importance of maintaining vegetation and replacement for the cycling of organic matter in environments that suffer from human pressures, such as that found in remnants.

\section{Acknowledgements}

To Fundação de Amparo a Pesquisa do Estado de São Paulo (FAPESP) and the Pontifícia Universidade Católica (Campinas/SP - Brazil.) 


\section{References}

[1] RAMBALDI, D.M; OLIVEIRA, D. A.S. Fragmentação de Ecossistemas: causas, efeitos sobre a biodiversidade e recomendações de políticas públicas. Brasília $2^{\mathrm{a}}$ Ed., MMA/SBF, 2005.

[2] VIANA, V.M.; PINHEIRO, L. A.F.V. Conservação da Biodiversidade em fragmentos florestais. Série Técnica IPEF, ESALQ/USP. v. 12, n.32, p 2542, dez, 1998. p. 25-42.

[3] KORMAN, Vânia. Proposta de integração das glebas do Parque Estadual de Vassununga (Santa Rita do Passa Quatro, SP). 2003. 131 p. Dissertação (Mestrado em Ecologia de Agroecossistemas). Escola Superior de Agricultura Luiz de Queiroz. Universidade de São Paulo. Piracicaba. 2003.

[4] Plano Local de Gestão Urbana de Barão Geraldo. Prefeitura Municipal de Campinas. Secretaria de Planejamento e Meio Ambiente. 1996.

[5] RAIJ, B. van et al. Análise química do solo para fins de fertilidade. Campinas. Fundação Cargill, 1997. 170p.

[6] CAMARGO, O.A.; MONIZ,A.C.; JORGE, J.A.; VALADARES, J.M.A.S. Métodos de análise química e física de solos no IAC. Campinas, IAC, 2009. 94 p. (B. técnico, 106.

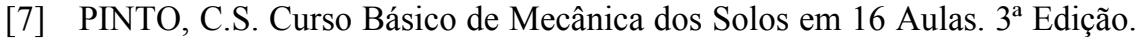
São Paulo, Oficina de Textos. 355 p. 2006.

[8] FERREIRA, G.C. Mecânica dos Solos A. Apostila da faculdade de Engenharia Civil da Pontifícia Universidade Católica de Campinas. s.d.

[9] BANZATO, D.A., KRONKA, M.R. Experimentação agrícola. 2 ed. Jaboticabal. Funep, 1992. 247p.

[10] SILVA, A.J.N.; RIBEIRO, M.R. Caracterização de Latossololo Amarelo sob cultivo contínuo de cana-de-açúcar no estado de Alagoas: atributos morfológicos e físicos. Revista Brasileira de Ciência do Solo, Viçosa, v. 21, n. 4, p 677-684, 1997.

[11] CAMARGO, O.A.; MONIZ,A.C.; JORGE, J.A.; VALADARES, J.M.A.S. Métodos de análise química e física de solos no IAC. Campinas, IAC, 2009. 94 p. (B. técnico, 106.

[12] SILVA, M.S.L., RIBEIRO, M.R. Influência do cultivo contínuo de canade-açúcar nas propriedades morfológicas e físicas de solos argilosos de tabuleiro no estado de Alagoas. Revista Brasileira de Ciência do Solo, Campinas, v.16, n.3. p.397-202, 1992. 